\title{
Characterization of a Hyperthermostable Alkaline Lipase from Bacillus sonorensis $4 \mathbf{R}$
}

\author{
Hemlata Bhosale, Uzma Shaheen, and Tukaram Kadam \\ DST-FIST Sponsored School of Life Sciences, Swami Ramanand Teerth Marathwada University, Nanded 431606, India \\ Correspondence should be addressed to Hemlata Bhosale; bhoslehemlata@gmail.com
}

Received 30 September 2015; Revised 14 December 2015; Accepted 22 December 2015

Academic Editor: Jean-Marie Dupret

Copyright (C) 2016 Hemlata Bhosale et al. This is an open access article distributed under the Creative Commons Attribution License, which permits unrestricted use, distribution, and reproduction in any medium, provided the original work is properly cited.

\begin{abstract}
Hyperthermostable alkaline lipase from Bacillus sonorensis $4 \mathrm{R}$ was purified and characterized. The enzyme production was carried out at $80^{\circ} \mathrm{C}$ and $9.0 \mathrm{pH}$ in glucose-tween inorganic salt broth under static conditions for $96 \mathrm{~h}$. Lipase was purified by anion exchange chromatography by 12.15 fold with a yield of $1.98 \%$. The molecular weight of lipase was found to be 21.87 KDa by SDS-PAGE. The enzyme activity was optimal at $80^{\circ} \mathrm{C}$ with $t_{1 / 2}$ of $150 \mathrm{~min}$ and at $90^{\circ} \mathrm{C}, 100^{\circ} \mathrm{C}, 110^{\circ} \mathrm{C}$, and $120^{\circ} \mathrm{C}$; the respective values were $121.59 \mathrm{~min}$, $90.01 \mathrm{~min}, 70.01 \mathrm{~min}$, and $50 \mathrm{~min}$. The enzyme was highly activated by $\mathrm{Mg}$ and $t_{1 / 2}$ values at $80^{\circ} \mathrm{C}$ were increased from $150 \mathrm{~min}$ to $180 \mathrm{~min}$ when magnesium and mannitol were added in combination. The activation energy calculated from Arrhenius plot was $31.102 \mathrm{KJ} / \mathrm{mol}$. At $80-120^{\circ} \mathrm{C}$, values of $\Delta H$ and $\Delta G$ were in the range of $28.16-27.83 \mathrm{KJ} / \mathrm{mol}$ and $102.79 \mathrm{KJ} / \mathrm{mol}$ to $111.66 \mathrm{KJ} / \mathrm{mol}$, respectively. Lipase activity was highest at $9.0 \mathrm{pH}$ and stable for 2 hours at this $\mathrm{pH}$ at $80^{\circ} \mathrm{C}$. Pretreatment of lipase with $\mathrm{MgSO}_{4}$ and $\mathrm{CaSO}_{4}$ stimulated enzyme activity by $249.94 \%$ and $30.2 \%$, respectively. The enzyme activity was greatly reduced by $\mathrm{CoCl}_{2}, \mathrm{CdCl}_{2}$, $\mathrm{HgCl}_{2}, \mathrm{CuCl}_{2}, \mathrm{~Pb}\left(\mathrm{NO}_{3}\right)_{2}, \mathrm{PMSF}$, orlistat, oleic acid, iodine, EDTA, and urea.
\end{abstract}

\section{Introduction}

Hyperthermophiles are the group of organisms growing at temperatures between 80 and $110^{\circ} \mathrm{C}$. This group is represented by bacterial and archeal species found in all types of terrestrial and marine hot environments. The hyperthermophilic enzymes or thermozymes derived from these organisms exhibit extreme thermostability and highest activity at temperatures above $70^{\circ} \mathrm{C}[1]$, some being highly active at and above $110^{\circ} \mathrm{C}[2]$. Hence, such enzymes are used as model systems for enzyme based research including enzyme research, molecular basis of thermostability, and deciding the upper temperature limit for enzyme function. Thermozymes are extremely stable and active at high temperatures and offer many biotechnological advantages over mesophilic enzymes such as easier purification by heat treatment, higher resistance to chemical denaturants, and reduced risk of microbial contamination [1]. They also offer high reaction rates and process yields by lowering viscosity, causing increased diffusion rates and substrate availability and maintaining favorable equilibrium with endothermal reactions [3]. Thermozymes isolated from hyperthermophiles growing at the temperature range of $80-110^{\circ} \mathrm{C}$ are expected to be more thermostable than their mesophilic correspondents as these organisms are in full harmony with the existing thermal conditions and expected to secrete the enzymes that are completely stable at these temperatures to support their physiological processes [4].

Lipases are the most important group of industrial biocatalysts that can be applied both as hydrolases and as synthetases and proved their enormous potential in various biotechnological applications. The unique characters of lipases such as high stability in organic solvents, their broad substrate specificity, and high enantioselectivity greatly increased their demand in industrial market. The current market scenario of hydrolytic enzymes positioned lipases at the top third rank after proteases and amylases and their annual market is targeted to reach about 590.5 million dollars by 2020 [5]. However, most of the industrial processes operate at relatively high temperature and alkaline $\mathrm{pH}$ conditions. Hence, the thermoalkalostability of lipases is one of the desired characteristics to endure harsh processing conditions used during industrial applications. Thermostable lipases are 
the need of food, cosmetics, detergent, and pharmaceutical industries $[6,7]$.

Most of the research on lipases is concentrated on isolating highly thermostable lipases from different thermophilic microbial sources. While thermostable lipases are known to be produced by Bacillus sp. which have unique protein sequence and inherent biochemical properties, lipases from Burkholderia ambifaria YCJ01 [8], Aneurinibacillus thermoaerophilus strain HZ [9], and Pseudomonas sp. [10] are also reported. However, the studies related to thermoalkalostable lipases from hyperthermoalkalophilic organisms are scanty. In the present study we are reporting for the first time the isolation and identification of highly thermostable lipase producing hyperthermophilic strain of Bacillus sonorensis 4R. Purification of enzyme and its thermodynamic and biochemical properties are also reported.

\section{Materials and Methods}

2.1. Materials. All media ingredients, diethylaminoethylcellulose (DEAE-cellulose), phenylmethylsulfonyl fluoride (PMSF), and bovine serum albumin (BSA), were purchased from HiMedia. All other chemicals used were of analytical grade.

2.2. The Lipolytic Organism and Enzyme Production. The lipolytic strain of Bacillus sonorensis $4 \mathrm{R}$ used in the present study was isolated from Thar Desert ecosystem of Jaisalmer, Rajasthan, India (lat. $27^{\prime} 00 \mathrm{~N}$ and $71^{\circ} 00 \mathrm{E}$ ). The strain was grown on alkaline tributyrin inorganic salt agar $(\mathrm{g} / \mathrm{L}$ : $\mathrm{K}_{2} \mathrm{HPO}_{4}, 1 ; \mathrm{MgSO}_{4}, 1 ; \mathrm{NaCl}, 1 ;$ ammonium sulphate, 2; $\mathrm{CaCO}_{3}, 2 ; \mathrm{FeSO}_{4}, 0.001 ; \mathrm{MnCl}_{2}, 0.001 ; \mathrm{ZnCl}_{2}, 0.001$; and tributyrin, $10 \mathrm{~mL}$ ) at $\mathrm{pH} 9.0,80^{\circ} \mathrm{C}$ for 7 days. Lipase production was carried out by growing active culture of $4 \mathrm{R}$ (5\%) in $2 \mathrm{~L}$ glucose-tween inorganic salt broth (g/L: $\mathrm{K}_{2} \mathrm{HPO}_{4}$, $1 ; \mathrm{MgSO}_{4}, 1 ; \mathrm{NaCl}, 1$; ammonium sulphate, 2; $\mathrm{CaCO}_{3}, 2$; $\mathrm{FeSO}_{4}, 0.001 ; \mathrm{MnCl}_{2}, 0.001 ; \mathrm{ZnCl}_{2}, 0.001$; glucose $10, \mathrm{CaSO}_{4}$, $100 \mathrm{mM}$; and tween-80, $10 \mathrm{~mL}$ ) adjusted to $\mathrm{pH} 9.0$. The flasks were incubated at $80^{\circ} \mathrm{C}$ for 4 days under static conditions. At the end of incubation, the culture broth was centrifuged at $10,000 \mathrm{rpm}$ for $30 \mathrm{~min}$ at $4^{\circ} \mathrm{C}$ to obtain cell-free supernatant. The supernatant was used as crude source of Bacillus sonorensis lipase (BSL) and analyzed for lipase activity and protein content.

2.3. Identification of Lipolytic Organism. Bacterial genomic DNA was isolated using geneO-spin Microbial DNA Isolation Kit (geneOmbio Technologies, Pune, India). This DNA was used as template for PCR analysis using the primers 27F: $5^{\prime}$-AGAGTTTGATCMTGGCTCAG-3' and 1492R: $5^{\prime}-$ TACCTTGTTACGACTT- $3^{\prime}$. The amplification conditions were $95^{\circ} \mathrm{C}$ for $10 \mathrm{~min}, 57^{\circ} \mathrm{C}$ for $1 \mathrm{~min}, 72^{\circ} \mathrm{C}$ for $90 \mathrm{sec}$, and final amplification at $72^{\circ} \mathrm{C}$ for $10 \mathrm{~min}$. The PCR products were purified by using a geneO-spin PCR Product Purification Kit (geneOmbio Technologies, Pune, India) and were directly sequenced using an ABI PRISM BigDye Terminator V3.1 Kit (Applied Biosystems, USA). The sequences were analyzed using Sequencing Analysis 5.2 software.
BLAST analysis was performed at BlastN site at NCBI server (http://www.ncbi.nlm.nih.gov/BLAST) and evolutionary relationship of $4 \mathrm{R}$ was deduced by constructing phylogenetic tree.

2.4. Lipase Assay and Protein Determination. The assay was performed by using the modified method described by Selvam et al. [11] based on olive oil hydrolysis. To the reaction mixture containing $1 \mathrm{~mL}$ of tris- $\mathrm{HCl}$ buffer ( $\mathrm{pH} 9.0$ ), $2.5 \mathrm{~mL}$ of deionized water, and $3 \mathrm{~mL}$ of olive oil emulsion $(10 \%$ gum arabic emulsified with $5 \%$ olive oil), $1 \mathrm{~mL}$ of crude enzyme for test and $1 \mathrm{~mL}$ of deionized water for blank were added in separate tubes. The reaction mixture was mixed thoroughly by swirling and incubated at $80^{\circ} \mathrm{C}$ for $30 \mathrm{~min}$. After incubation, enzyme substrate reaction was terminated by addition of $3 \mathrm{~mL}$ of $95 \%$ ethanol and mixed by swirling. The amount of fatty acids liberated due to lipase activity was estimated by titrating the contents of assay mixture against $0.05 \mathrm{M} \mathrm{NaOH}$ using thymolphthalein as a $\mathrm{pH}$ indicator. The end point observed was from colorless to light blue. One unit of lipase was defined as the amount of enzyme required to release $1 \mu \mathrm{mole}$ of fatty acid under assay conditions. Protein content of all fractions was determined by Bradford assay [12] by using BSA as a standard protein.

2.5. BSL Purification. The crude lipase was purified using a two-step procedure including ammonium sulphate precipitation followed by dialysis and DEAE-cellulose ion exchange chromatography. The cell-free supernatant was pretreated at $80^{\circ} \mathrm{C}$ for $30 \mathrm{~min}$ to eliminate the appearance of additional proteins and brought to $80 \%$ saturation by adding finely powdered ammonium sulphate. The flask was kept overnight at $4^{\circ} \mathrm{C}$ and the precipitate was collected by centrifugation at $10,000 \mathrm{rpm}$ for $20 \mathrm{~min}$ at $4^{\circ} \mathrm{C}$. The precipitate was dissolved in phosphate buffer $(0.1 \mathrm{M}, \mathrm{pH} 9.0)$ and dialyzed overnight against the same buffer.

The desalted enzyme obtained from dialysis step was loaded on chromatography column $(1.5 \times 15 \mathrm{~cm})$ packed with DEAE-cellulose and preequilibrated with $0.1 \mathrm{M}$ phosphate buffer ( $\mathrm{pH}$ 9.0). The enzyme was eluted with linear gradient of $\mathrm{NaCl}(0.1-0.5 \mathrm{M})$ in phosphate buffer. The flow rate of column was adjusted to $0.5 \mathrm{~mL} / \mathrm{min}$ and protein concentration (280 nm, UV Vis Shimadzu) and lipase activity of eluted fractions were determined as mentioned before after desalting.

2.6. Determination of Molecular Mass of BSL. The molecular mass of purified BSL was determined by sodium dodecyl sulphate polyacrylamide gel electrophoresis (SDSPAGE) technique using HiPer SDS-PAGE Kit (HiMedia) according to the manufacturer's instructions. A broad range of unstained protein standards (insulin [3.5 kda], aprotinin [6.5 kda], lysozyme [14.3 kda], soya bean trypsin inhibitor [20.1 kda], carbonic anhydrase [29.0 kda], ovalbu$\min [43.0 \mathrm{kda}$ ], BSA [66.0 kda], phosphorylase [97.4 kda], and myosin [205.0 kda]) was used as molecular mass makers. The gel was stained with $0.025 \%$ Coomassie Brilliant Blue R-250 staining solution provided in the kit and destained 
overnight by adding $7 \%$ acetic acid solution. The molecular mass of purified BSL was determined from a plot between $\log$ MW and relative migration values $\left(R_{f}\right)$ of standard protein markers. The activity of purified fraction obtained after electrophoresis was confirmed by zymogram analysis. The gel was prepared by supplementing $1 \%$ tributyrin; the sample was loaded and subjected to electrophoresis. The gel was stained and destained as mentioned before and the location of band on gel was observed for presence of clear zone due to tributyrin hydrolysis.

2.7. Effect of Temperature on BSL Activity and Stability. The optimum temperature for BSL activity was determined over the temperature range of $80-120^{\circ} \mathrm{C}(80,90,100,110$, and $120^{\circ} \mathrm{C}$ ) by preincubating aliquots of purified lipase in phosphate buffer (100 mM, pH 9.0) at respective temperatures for $30 \mathrm{~min}$. After incubation, the fractions were cooled on ice and assayed for BSL activity. To determine the effect of temperature on enzyme stability, different aliquots of purified enzyme were preincubated separately at $80-120^{\circ} \mathrm{C}$ for $3 \mathrm{~h}$ in phosphate buffer $(100 \mathrm{mM}, \mathrm{pH} 9.0)$ and residual activity was measured at intervals of $30 \mathrm{~min}$.

2.8. Effect of Divalent Cations and Polyols on Thermostability of BSL. The effect of varying concentrations of $\mathrm{CaSO}_{4}$ and $\mathrm{MgSO}_{4}$ and different polyols including glycerol (3C), ethylene glycol (5C), inositol (5C), sorbitol (5C), and mannitol (6C) on thermal stability of BSL was studied by preincubating various enzyme fractions in presence of respective compounds at $80^{\circ} \mathrm{C}$ for $3 \mathrm{~h}$. The aliquots were withdrawn after every $30 \mathrm{~min}$, ice-cooled, and used for residual activity determination. The activity was compared with initial lipase activity observed before incubation in presence of $\mathrm{Ca}, \mathrm{Mg}$, and polyols. The polyol showing improved thermostability was selected over the range of $20-100 \mathrm{mM}$ for further study at $80^{\circ} \mathrm{C}$. Similarly, cumulative effect of selected polyol $(60 \mathrm{mM})$ and $\mathrm{MgSO}_{4}(80 \mathrm{mM})$ on thermostability of BSL was determined.

2.9. Thermodynamic Parameters. The thermodynamic parameters related to BSL activity at elevated temperatures (80$\left.120^{\circ} \mathrm{C}\right)$ were determined in terms of half-life $\left(t_{1 / 2}\right)$, denaturation constant $\left(K_{d}\right)$, enthalpy of denaturation $(\Delta H)$, free energy of denaturation $(\Delta G)$, and entropy of denaturation $(\Delta S)$. The inactivation rate constants were calculated from a plot of residual activity versus time and used for estimating half-lives. The activation energy of thermal inactivation $\left(E_{a}\right)$ was determined from the Arrhenius plot between $\ln K_{d}$ and $1 / T(K)$ as described before [13]. The values of $\Delta H, \Delta G$, and $\Delta S$ for inactivation were calculated according to the following equations, respectively, as described by Gummadi [14]:

$$
\begin{aligned}
& \Delta H=E_{a}-R T \\
& \Delta G=-R T \ln \left(\frac{K_{d} \cdot h}{K_{b} \cdot T}\right) \\
& \Delta S=(\Delta H-\Delta G) T,
\end{aligned}
$$

where $R=8.314 \mathrm{JK}^{-1} \mathrm{~mol}^{-1}$ is the universal gas constant, $T$ is absolute temperature, $h$ is Plank's constant, and $K_{b}$ is Boltzmann's constant.

2.10. Effect of $p H$ on BSL Activity and Stability. To determine the effect of pH on BSL activity, the aliquots of enzyme were preincubated in buffers of different $\mathrm{pH}$ values (sodium phosphate, $0.1 \mathrm{M}, \mathrm{pH} 7.5-8$; tris- $\mathrm{HCl}, 0.1 \mathrm{M}, 8.5-9.0$; carbonatebicarbonate, $0.1 \mathrm{M}, \mathrm{pH}$ 9.5-10.5; sodium phosphate- $\mathrm{NaOH}$, $0.1 \mathrm{M}, \mathrm{pH} 11-12$ ) for $30 \mathrm{~min}$ at $80^{\circ} \mathrm{C}$. After incubation the fractions were ice cooled and enzyme activity was determined under assay conditions. To determine the effects of $\mathrm{pH}$ on stability, aliquots of BSL were preincubated with buffer of $\mathrm{pH} 9.0$ for $180 \mathrm{~min}$ at $80^{\circ} \mathrm{C}$ and the residual activity was determined at intervals of $20 \mathrm{~min}$.

2.11. Effect of Metal Ions on BSL Activity. The effects of various metal ions, namely, $\mathrm{Ca}^{++}, \mathrm{Mg}^{++}, \mathrm{Cu}^{++}, \mathrm{Pb}^{++}, \mathrm{Co}^{++}, \mathrm{Cd}^{++}$, and $\mathrm{Hg}^{++}$, as $\mathrm{CaSO}_{4}, \mathrm{MgSO}_{4}, \mathrm{CuCl}_{2}, \mathrm{~Pb}\left(\mathrm{NO}_{3}\right)_{2}, \mathrm{CoCl}_{2}$, and $\mathrm{HgCl}_{2}$ on BSL activity were studied. The aliquots of BSL $(10 \mu \mathrm{L})$ were preincubated in presence of different metal ion concentrations $(25-150 \mathrm{mM})$ at $80^{\circ} \mathrm{C}$ for $30 \mathrm{~min}$ and subjected to lipase assay. The effect of metal ions on BSL activity was determined by comparing the enzyme activities in absence of these compounds.

2.12. Effect of Chemical Modulators on BSL Activity. The effect of different chemical modulators on BSL activity was tested by preincubation of properly diluted enzyme at $80^{\circ} \mathrm{C}$ for $30 \mathrm{~min}$ in presence of selected chemical modulators. The chemical modulators (ethylene diamine tetra-acetic acid (EDTA), urea, PMSF, iodine, orlistat, and oleic acid) were set at $5 \mathrm{mM}$ and after preincubation, BSL activity was determined under assay conditions. The effect of chemical modulators on BSL activity was determined by comparing the enzyme activities in absence of these compounds.

\section{Results and Discussion}

3.1. Growth and Lipase Production by Bacillus sonorensis $4 R$. The lipase producing Bacillus sonorensis 4R, isolated from soils of Thar Desert area in Jaisalmer, Rajasthan, India, was detected using tributyrin agar plates. The isolate showed good tributyrin hydrolysis efficiency on plates $(28 \mathrm{~mm}$ ) (Figure 1) as well as in broth $(51.33 \mathrm{U} / \mathrm{mL})$ after 4 days of incubation at $80^{\circ} \mathrm{C}$. The hyperthermoalkalophilic bacteria optimally grow within temperature range of $80-110^{\circ} \mathrm{C}$ and are found in all terrestrial and marine hot environments. The selected soil sample of Thar Desert after enrichment in inorganic salt medium supplemented with $1 \%$ tributyrin at $80^{\circ} \mathrm{C}$ and $\mathrm{pH} 9.0$ successfully isolated potential lipase producing thermoalkalophilic strain of $4 \mathrm{R}$.

The isolate was identified as Bacillus sonorensis on the basis of its morphological characteristics and 16S rRNA sequencing. The $4 \mathrm{R}$ strain has ability to grow at temperature between 80 and $100^{\circ} \mathrm{C}$ and $8.0-11.0 \mathrm{pH}$ with optimum growth at $80^{\circ} \mathrm{C}$ and $\mathrm{pH}$ 9.0. It appeared as a facultative anaerobe, 


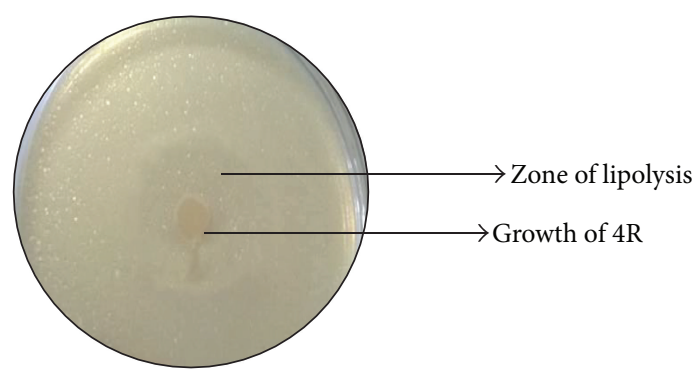

FIGURE 1: Lipase producing bacterial isolate Bacillus sonorensis 4R: colonies on tributyrin agar showing zone of lipolysis after 4 days of incubation at $80^{\circ} \mathrm{C}$ and $\mathrm{pH} 9.0$.

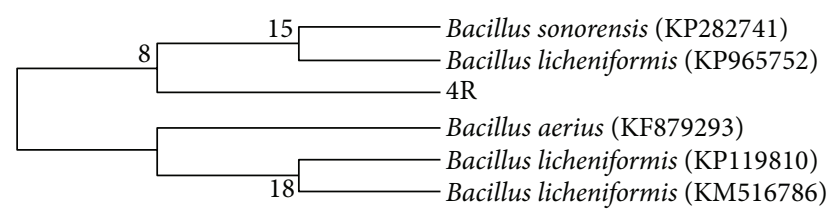

FIGURE 2: Neighbor joining tree based on $16 \mathrm{~S}$ gene sequencing showing phylogenetic relationship between Bacillus sonorensis $4 \mathrm{R}$ and related members of the genus Bacillus.

Gram-positive long rod, nonmotile, catalase positive bacterium and had the capacity to reduce nitrate and produced acid from glucose, arabinose, xylose, and mannitol. The 1286base-pair sequence obtained by $16 \mathrm{~S}$ rRNA sequencing has been deposited to NCBI gene bank database with accession number KT 368092. Bacillus sonorensis 4R shared the highest homology of $100 \%$ with Bacillus sonorensis strain ZJY-537. From the phylogenetic analysis it was confirmed that $4 \mathrm{R}$ was closely associated with Bacillus sonorensis which is a close lineage of Bacillus licheniformis and other members of genus Bacillus (Figure 2). Hence, the strain $4 \mathrm{R}$ was identified as Bacillus sonorensis. So far, Bacillus sonorensis was reported to be isolated from Sonoran Desert [15] and Kalbadevi estuary, Mumbai [16]. Abundance of thermophilic Bacillus species including Bacillus licheniformis, Bacillus aerius, Bacillus sonorensis, Bacillus subtilis, and Bacillus amyloliquefaciens in hot springs, salt marshes, and desert soil of Morocco has been observed by Aanniz et al. [17]. The study also highlighted the growth of isolated Bacillus species at temperature range between 30 and $80^{\circ} \mathrm{C}$. All species of Bacillus sonorensis showed good growth from 30 to $55^{\circ} \mathrm{C}$ whereas none of the isolates grew above $70^{\circ} \mathrm{C}$. Different studies have reported the dominance of strains of Bacillus species in various geothermal habitats including Japanese desert [18] and Atacama Desert soil [19] with special reference of common occurrence of Bacillus sonorensis in deserts of Morocco [15]. However, the hyperthermophilic growth at $80^{\circ} \mathrm{C}$ and above temperatures and lipase production capacity of Bacillus sonorensis were not reported earlier. Only few reports on sonorensin, a food preservative [20], and lipopeptide antibiotic production [21] by strain of Bacillus sonorensis are available. In this context, we are reporting for the first time the isolation of hyperthermophilic lipase producing Bacillus sonorensis from Thar Desert of Rajasthan.

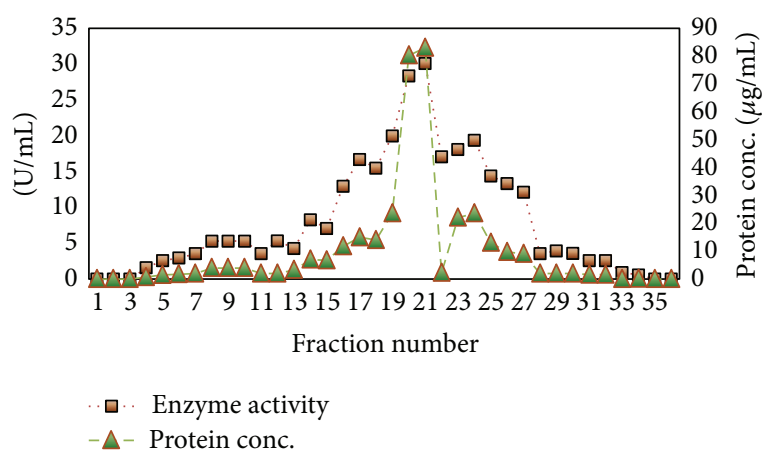

FIGURE 3: Elution profile of BSL for purification on DEAE-cellulose column.

3.2. Purification of BSL. The lipase produced by Bacillus sonorensis was purified by using a sequential procedure including salt precipitation, desalting by dialysis, and chromatography on DEAE-cellulose column. The results of the lipase purification profile are summarized in Table 1. The enzyme was finally purified 12.15 -fold over crude extract with $1.98 \%$ recovery.

Chromatography of lipase on DEAE-cellulose ion exchange column resulted in one prominent peak at the 21st fraction (Figure 3). The active fractions were pooled and the homogeneity of purified enzyme was confirmed by the presence of a single band corresponding to an apparent molecular mass of 21.87 KDa on SDS-PAGE gel (Figure 4(a)). Lipase activity in the purified band was checked by observing presence of lipolysis zone in gels supplemented with $1 \%$ tributyrin (Figure 4(b)).

3.3. Effect of Temperature on BSL Activity. The effect of different temperatures on activity of purified lipase is shown in Figure 5(a). Bacillus sonorensis produced lipase was more active in temperature range of $80-120^{\circ} \mathrm{C}$ with more than $50 \%$ of its original activity remaining above $90^{\circ} \mathrm{C}$ up to $120^{\circ} \mathrm{C}$ after $30 \mathrm{~min}$ exposure (Figure $5(\mathrm{~b})$ ). The optimum temperature recorded for the lipase activity of TM12350, a recombinant lipase from a hyperthermophilic bacterium Thermotoga maritima, was $70^{\circ} \mathrm{C}$ [22] with maximum activity retained for $60 \mathrm{~min}$ at $70^{\circ} \mathrm{C}$ while maintaining more than its $50 \%$ activity within $8 \mathrm{~h}$. At higher temperature the confirmation of enzyme is disrupted which results in reduced affinity sites for substrate [23]. Hence, in the present study when the temperature was increased from 80 to $120^{\circ} \mathrm{C}$, a gradual decrease in catalytic activity of BSL was observed. However, the degree by which the activity was decreased was not convincing as BSL retained more than $50 \%$ of its original activity at $120^{\circ} \mathrm{C}$. The lipase exhibited significant stability at $80^{\circ} \mathrm{C}$ with a half-life $\left(t_{1 / 2}\right)$ of $150 \mathrm{~min}$ whereas the values of $t_{1 / 2}$ reduced to $121.59 \mathrm{~min}, 90.01 \mathrm{~min}, 70.01 \mathrm{~min}$, and $50 \mathrm{~min}$, respectively, at $90^{\circ} \mathrm{C}$ and above temperatures $\left(100^{\circ} \mathrm{C}, 110^{\circ} \mathrm{C}\right.$, and $\left.120^{\circ} \mathrm{C}\right)$ and at $\mathrm{pH} 9.0$. These characteristics indicated that BSL is a highly thermostable lipase retaining about $50 \%$ activity at and above $100^{\circ} \mathrm{C}$. This study for the first time showed the highly thermostable nature of lipase produced among Bacillus family and probably among all 
TABLE 1: Purification summary of hyperthermostable lipase from B. sonorensis 4R.

\begin{tabular}{|c|c|c|c|c|c|}
\hline & $\begin{array}{l}\text { Protein content } \\
\quad(\mathrm{mg} / \mathrm{mL})\end{array}$ & Total activity & $\begin{array}{l}\text { Specific activity } \\
(\mathrm{U} / \mathrm{mg})\end{array}$ & $\begin{array}{l}\text { Purification } \\
\text { fold }\end{array}$ & Yield (\%) \\
\hline Crude & 0.290 & 153990 & 177 & 1 & 100 \\
\hline $\begin{array}{l}\text { Ammonium sulphate } \\
\text { precipitation }\end{array}$ & 0.252 & 13275 & 351 & 1.98 & 8.62 \\
\hline Dialysis & 0.143 & 5901.5 & 825 & 4.67 & 3.83 \\
\hline $\begin{array}{l}\text { DEAE-cellulose } \\
\text { column }\end{array}$ & 0.355 & 3055.96 & 2152.08 & 12.15 & 1.98 \\
\hline
\end{tabular}

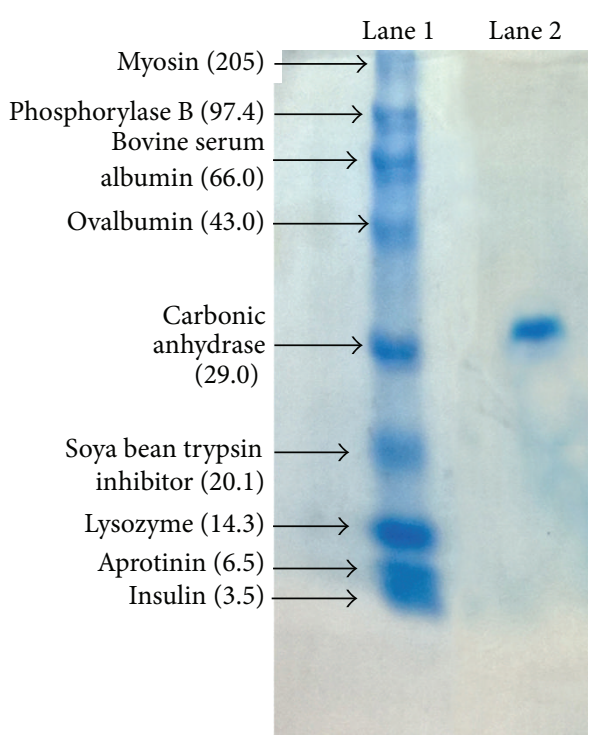

(a)

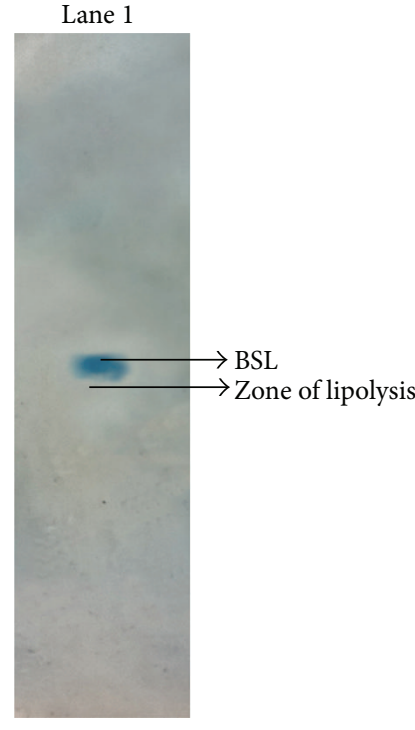

(b)

FIGURE 4: SDS-PAGE of hyperthermostable lipase from Bacillus sonorensis 4R. (a) Lane 1: standard protein molecular mass markers, Lane 2: purified BSL. (b) Activity characterization of BSL by zymogram analysis.

reported lipases. For lipase produced by Bacillus licheniformis MTCC6824, [24] reported $t_{1 / 2}$ values of $82 \mathrm{~min}, 75 \mathrm{~min}$, and $48 \mathrm{~min}$ at $45^{\circ} \mathrm{C}, 50^{\circ} \mathrm{C}$, and $55^{\circ} \mathrm{C}$ whereas Shariff et al. [25] showed thermoactive nature of $\mathrm{L}_{2}$ lipase at a temperature range of $55-80^{\circ} \mathrm{C}$ with temperature optima at $70^{\circ} \mathrm{C}$ and $t_{1 / 2}$ of $2 \mathrm{~h}$ at $60^{\circ} \mathrm{C}$. However, the reported thermostability at alkaline $\mathrm{pH}$ (9.0) in the present study was higher where enzyme was retaining its $50 \%$ activity at and above $100^{\circ} \mathrm{C}$. Lipases at high temperature and alkaline $\mathrm{pH}$ are of immense importance in food industry and pharmaceuticals due to their process conditions operating at high temperature (45$50^{\circ} \mathrm{C}$ ) and $\mathrm{pH}(8.0)$. The thermostability exhibited by BSL was greater than other thermostable lipases, such as lipase from Bacillus species SP 42 with $t_{1 / 2}$ of $45 \mathrm{~min}$ at $70^{\circ} \mathrm{C}[26]$, esterase from Thermoanaerobacter sp. with $t_{1 / 2}$ of $90 \mathrm{~min}$ at $70^{\circ} \mathrm{C}$ [27], and lipase from the hyperthermophilic Aneurinibacillus thermoaerophilus- $\mathrm{HZ}$ with half-life of $80 \mathrm{~min}$ at $70^{\circ} \mathrm{C}$. The enzymes activated at and above $40^{\circ} \mathrm{C}$ are said to undergone thermal activation [10]. In the present study the BSL was only activated at high temperatures $\left(80^{\circ} \mathrm{C}\right)$ and the activity was very poor at $40^{\circ} \mathrm{C}$ indicating thermal activation of BSL (Figure 5(c)). The characteristic of an enzyme to show thermal activation depends on the hydrophobic amino acid content of the protein and lipases are known to be rich in hydrophobic amino acids $[28,29]$. Hence, it is expected that the thermal activation of BSL in the present study might be contributed by its hydrophobic amino acids content.

3.4. Effect of Divalent Cations and Polyols on BSL Activity. The catalytic activity of BSL was greatly increased over control at $80^{\circ} \mathrm{C}$ in presence of $\mathrm{Ca}^{2+}$ and $\mathrm{Mg}^{2+}$ at all concentrations (20$100 \mathrm{mM}$ ). $\mathrm{CaSO}_{4}$ when used at $60 \mathrm{mM}$ and $80 \mathrm{mM}$ concentrations caused $249.08 \%$ and $199 \%$ respective enhancement in BSL activity whereas, with increase in incubation time, the activity was gradually decreased and reported absent after $3 \mathrm{~h}$ incubation at all concentrations (Figure 6(a)). BSL activity was also found to increase significantly in presence of $\mathrm{MgSO}_{4}$ (80 $\mathrm{mM})$ after 20-100 min exposure. The highest increase in activity was observed after $60 \mathrm{~min}$ incubation (423.6\%) and thereafter, the activity was slowly reduced (Figure 6(b)).

It has been reported earlier that the molecular size and number of hydroxyl groups per molecule of polyol play an important role in mediating the protection against thermal inactivation [30]. In this study mannitol appeared as the best thermoprotectant at $50 \mathrm{mM}$ concentration as observed in terms of approximately $20 \%$ enhancement in residual activity 

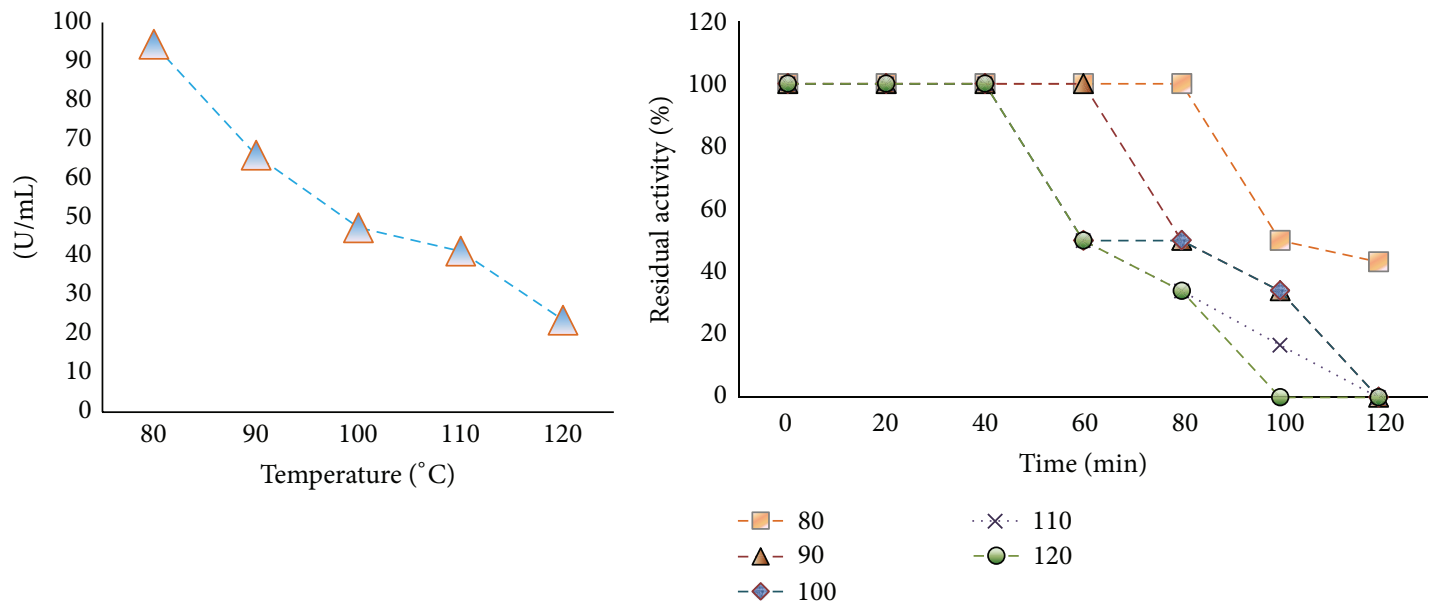

(a)

(b)

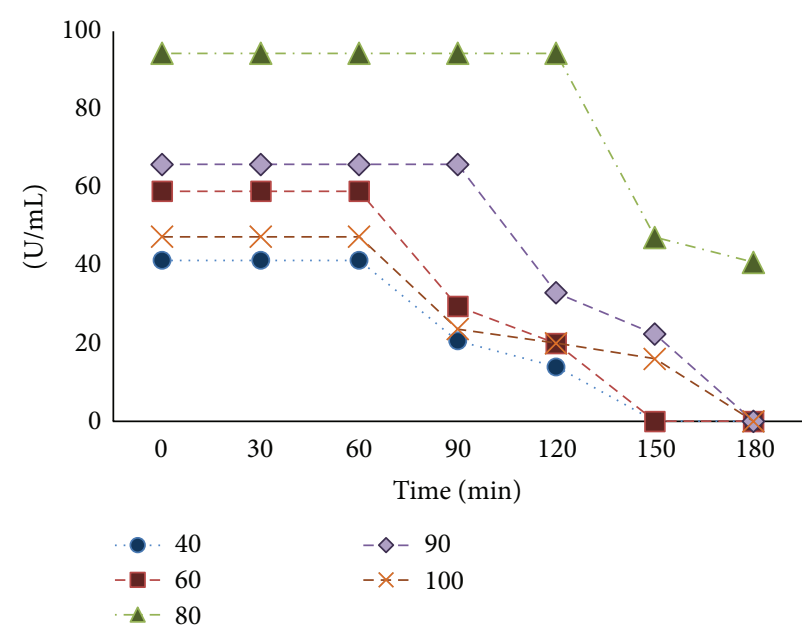

(c)

FIGURE 5: (a) Effect of temperature on BSL activity. (b) Thermostability of BSL at temperatures from 80 to $120^{\circ} \mathrm{C}$. (c) Thermal activation of BSL at elevated temperatures.

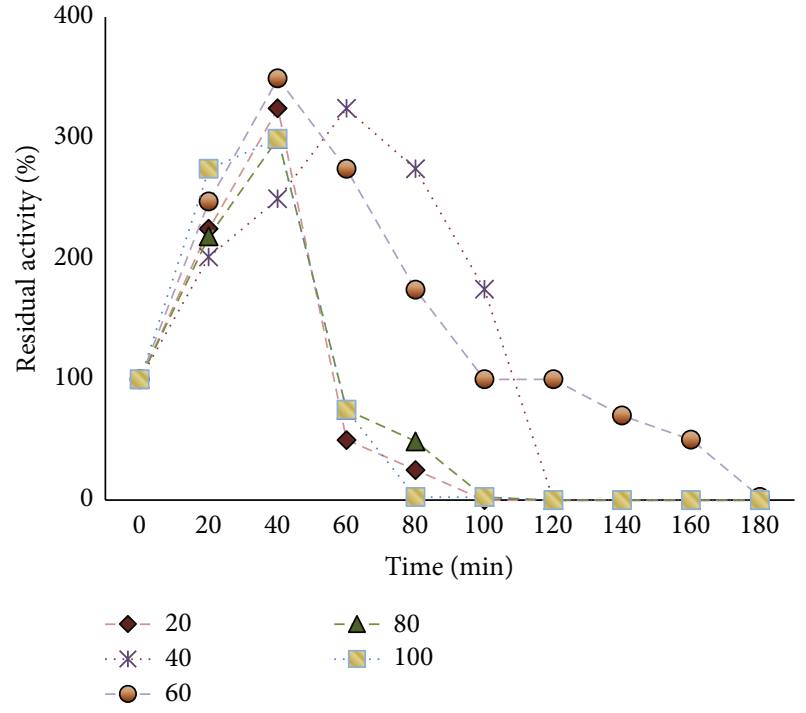

(a)

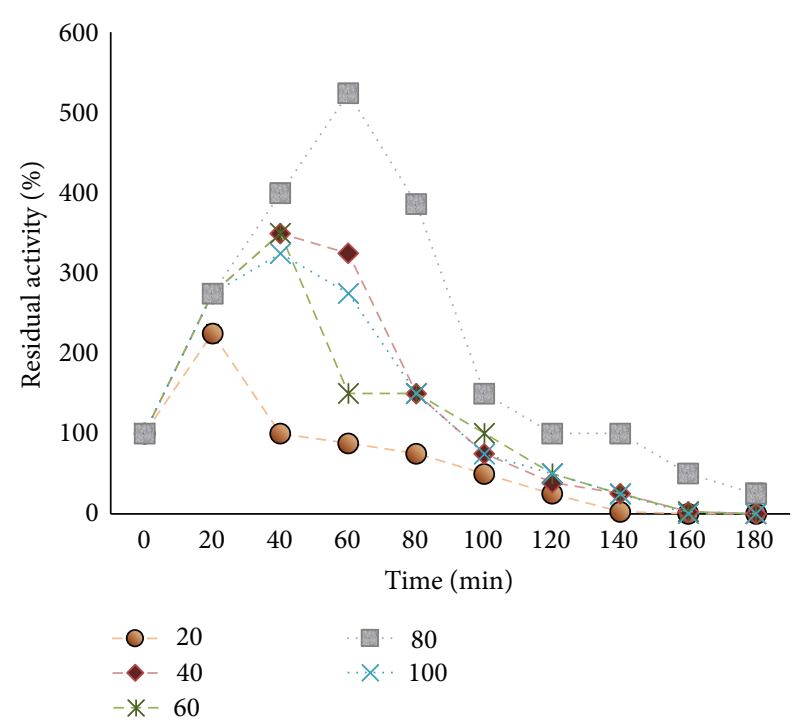

(b)

Figure 6: (a) Effect of $\mathrm{CaSO}_{4}(20-100 \mathrm{mM})$ on BSL thermostability. (b) Effect of $\mathrm{MgSO}_{4}(20-100 \mathrm{mM})$ on BSL thermostability. 


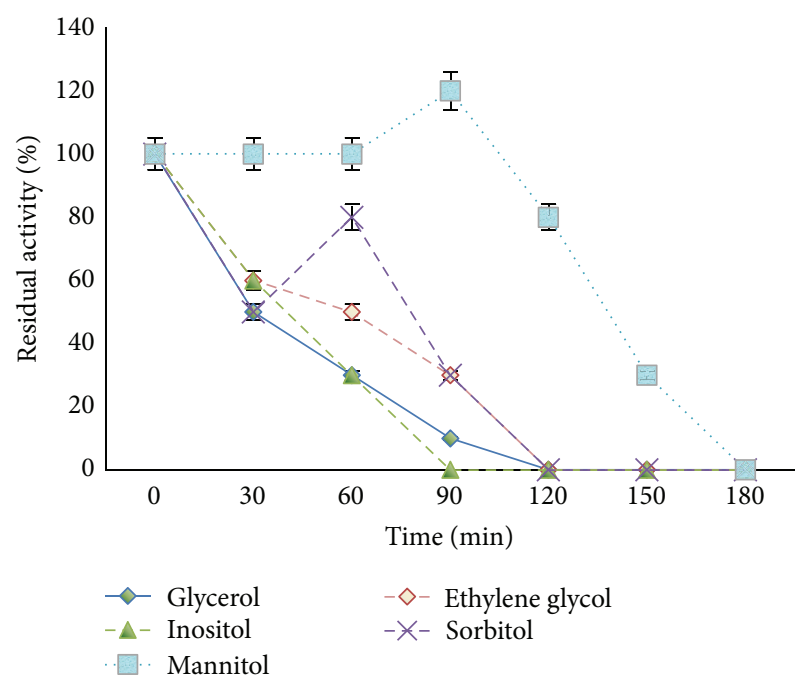

(a)

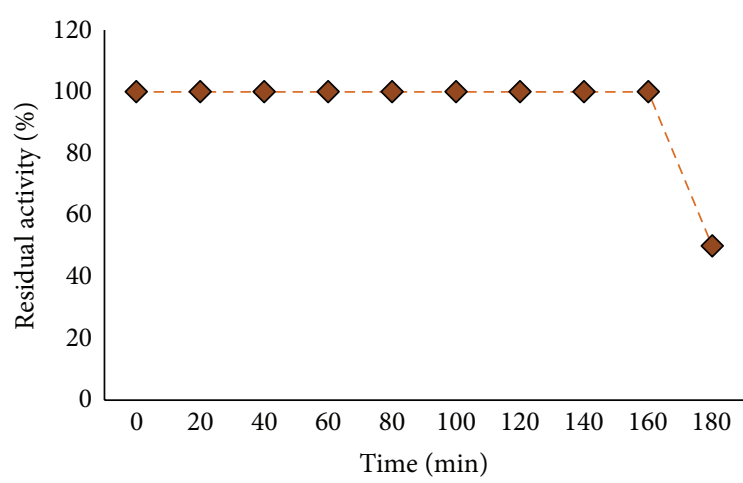

(c)

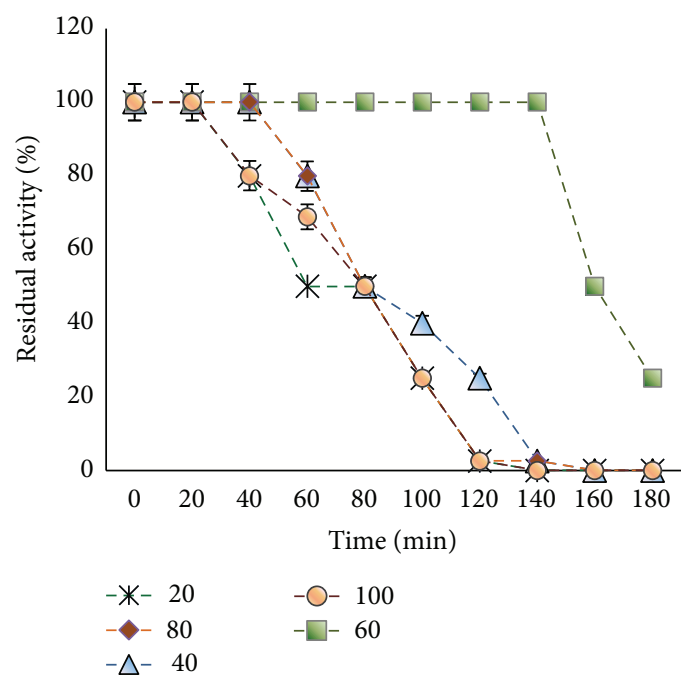

(b)

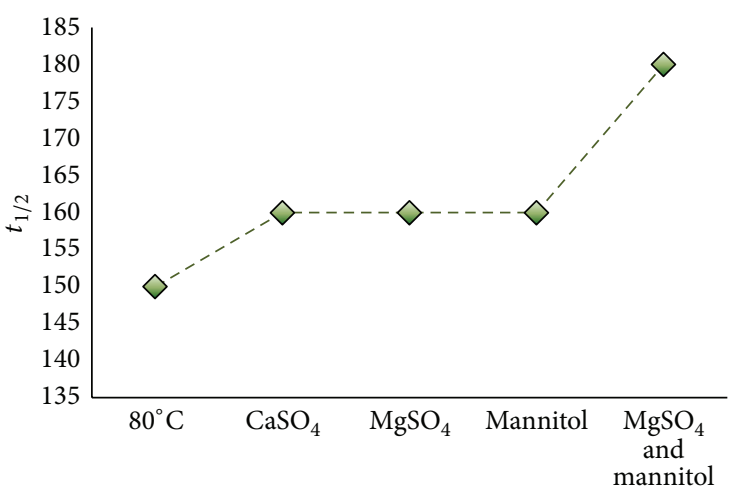

(d)

Figure 7: (a) Effect of different polyols (50 mM) on BSL activity. (b) Effect of mannitol (20-100 mM) on BSL thermostability. (c) Cumulative effect of $\mathrm{MgSO}_{4}(80 \mathrm{mM})$ and mannitol $(60 \mathrm{mM})$ on BSL thermostability. (d) $t_{1 / 2}$ values of BSL at $80^{\circ} \mathrm{C}, \mathrm{CaSO}_{4}(60 \mathrm{mM}), \mathrm{MgSO}_{4}(80 \mathrm{mM})$, mannitol $(60 \mathrm{mM})$, and $\mathrm{MgSO}_{4}(80 \mathrm{mM})$ and mannitol $(60 \mathrm{mM})$.

after 90 min exposure while retaining 100\% activity when incubated for $60 \mathrm{~min}$ (Figure $7(\mathrm{a})$ ). However, with further rise in incubation time, the activity was gradually reduced. The effect of different mannitol concentrations on thermostability of BSL was also evaluated. Increasing mannitol concentration up to $60 \mathrm{mM}$ improved the thermostability of BSL with $49.99 \%$ of the original activity remaining after $140 \mathrm{~min}$ at $80^{\circ} \mathrm{C}$. At higher concentration of mannitol $(100 \mathrm{mM})$ reduced thermostability was observed where $100 \%$ of residual activity was retained only for $60 \mathrm{~min}$ (Figure 7(b)). Addition of polyols can prevent conformational changes of the enzyme by promoting formation of numerous hydrogen bond or salt bridges between amino acid residues, making the enzyme molecule more rigid and, hence, more resistant to the thermal unfolding [31, 32]. However, the selection of the suitable additive depends on the nature of enzyme and it varies from one enzyme to another. Addition of polyols improves thermostability of lipase from Bacillus licheniformis MTCC6824 [24], xylanases from Trichoderma reesei QM9414 [33], and xylanase from A. pullulans CBS135684 [34]. The effect of sorbitol on thermostability of lipase has been identified in Bacillus licheniformis MTCC6824 [24]. The cumulative effect of $\mathrm{MgSO}_{4}(80 \mathrm{mM})$ and mannitol $(60 \mathrm{mM})$ on thermostability is shown in Figure 7(c). BSL incubated with a combination of $\mathrm{MgSO}_{4}$ and mannitol induced a synergistic effect observed in terms of $100 \%$ residual activity of BSL remained after $160 \mathrm{~min}$, as compared to $49.99 \%$ when incubated with $\mathrm{Mg}^{++}$ or mannitol alone. After $3 \mathrm{~h}, \mathrm{Mg}^{++}$and mannitol combination was found to retain approximately $50 \%$ of original activity as compared to approximately $25 \%$ in presence of $\mathrm{Mg}^{++}$ or mannitol alone. The $t_{1 / 2}$ values at $80^{\circ} \mathrm{C}$ were increased from $150 \mathrm{~min}$ to $180 \mathrm{~min}$ when magnesium and mannitol were added in combination (Figure $7(\mathrm{~d})$ ). The loss of enzyme activity at elevated temperature ranges is related to changes in enzyme conformation $[30,35]$. Improved thermostability of BSL due to $\mathrm{Mg}^{++}$and mannitol, a higher polyhydric alcohol, might be due to hindered denaturation of catalytic site of enzyme caused by hydration resulting in charge rearrangement and ion complexation. Ion complexation of metal ions such as $\mathrm{Ca}^{++}$is a process with favorable entropy factor that 


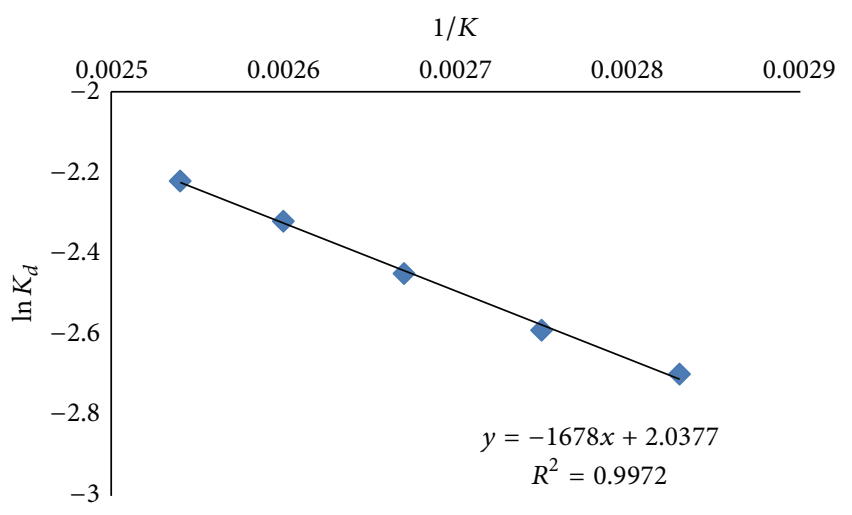

FIGURE 8: Arrhenius plot for determination of the activation energy of BSL.

helps in stabilization of enzymes at high temperatures. The role of $\mathrm{Ca}^{++}$ions in maintenance of stable and active enzyme structure is well stated [24]. However, the Mg and mannitol dependent improvement of hyperthermostable lipases is not reported earlier.

3.5. Thermodynamic Characteristics. The effects of varying temperatures on kinetic and thermodynamic characteristics of BSL are summarized in Table 2. The parameters including half-life period, denaturation constant, entropy, enthalpy, and free energy change at different temperatures were determined from Arrhenius plot as shown in Figure 8. The activation energy calculated from Arrhenius plot was $31.102 \mathrm{KJ} / \mathrm{mol}$ at $80^{\circ} \mathrm{C}$; the $t_{1 / 2}$ value was $150 \mathrm{~min}$ and it appeared to reduce to $121.59 \mathrm{~min}$ at $90^{\circ} \mathrm{C}$. Further, increase in temperatures reduced half-lives of BSL to $90.01 \mathrm{~min}, 70.01 \mathrm{~min}$, and $50 \mathrm{~min}$ appearing at $100^{\circ} \mathrm{C}, 110^{\circ} \mathrm{C}$, and $120^{\circ} \mathrm{C}$, respectively. The values of denaturation constant were increased with increase in temperature from 80 to $120^{\circ} \mathrm{C}$. The values of $\Delta H$ were not changed significantly from 80 to $120^{\circ} \mathrm{C}$ and recorded in the range of $28.16-27.83 \mathrm{KJ} / \mathrm{mol}$. $\Delta G$ was increased from $102.79 \mathrm{KJ} / \mathrm{mol}$ at $80^{\circ} \mathrm{C}$ to $111.66 \mathrm{KJ} / \mathrm{mol}$ at $120^{\circ} \mathrm{C}$. It was reported previously that thermodynamically stable proteins exhibit high $\Delta G$ [36]. The appearing high values of free energy change in denaturation in the present study confirmed the thermodynamic stability of BSL and its better resistance against thermal unfolding conferred at elevated temperatures. This was further supported by observed entropy values. The change in entropy was not noticeable from 80 to $120^{\circ} \mathrm{C}$ demonstrating nominal changes in enzyme architecture during thermal unfolding.

3.6. Effect of pH on BSL Activity and Stability. BSL exhibited good activity over the $\mathrm{pH}$ range $7.5-11$ (Figure 9(a)). The maximum activity was observed at $\mathrm{pH} 9.0(118.20 \mathrm{U} / \mathrm{mL})$ followed by $\mathrm{pH} 9.5(94.4 \mathrm{U} / \mathrm{mL})$ and $\mathrm{pH} 10(70.8 \mathrm{U} / \mathrm{mL})$. A rapid decline in the enzyme activity was observed beyond $\mathrm{pH}$ 10.0 whereas the activity was lowest at $\mathrm{pH} 12(10 \mathrm{U} / \mathrm{mL})$. At $\mathrm{pH}$ 9.0 BSL retained its $100 \%$ activity for $120 \mathrm{~min}$ (Figure 9(b)) followed by a sequential decrease in original enzyme activity from $140 \mathrm{~min}$ (49.99\%), $160 \mathrm{~min}$ (41.68\%), and $180 \mathrm{~min}(0 \%)$ exposure. Similarly, Jeagar et al. [25] reported maximum lipolytic activity of $\mathrm{L}_{2}$ lipase towards olive oil as a substrate retaining $50 \%$ of its original activity at $\mathrm{pH} 10.0$.

3.7. Effect of Metal Ions on BSL Activity. The effects of varying concentrations of metal ions $(25-150 \mathrm{mM})$ including $\mathrm{CaSO}_{4}$, $\mathrm{MgSO}_{4}, \mathrm{CuCl}_{2}, \mathrm{~Pb}\left(\mathrm{NO}_{3}\right)_{2}, \mathrm{CoCl}_{2}, \mathrm{CdCl}_{2}$, and $\mathrm{HgCl}_{2}$ on BSL activity are shown in Figure 10. A concentration dependent enhancement in lipase activity was found in presence of $\mathrm{MgSO}_{4}$. The residual activity was gradually increased from $100 \%$ to $349.94 \%$ with increase in $\mathrm{MgSO}_{4}$ concentration from $50 \mathrm{mM}$ to $150 \mathrm{mM}$, respectively. Addition of $\mathrm{CaSO}_{4}$ at concentration range of $50-150 \mathrm{mM}$ either retained $100 \%$ residual activity or caused a marginal enhancement in BSL activity. The activity was reduced drastically in presence of low concentrations of $\mathrm{CuCl}_{2}(25-75 \mathrm{mM})$ and $\mathrm{Pb}\left(\mathrm{NO}_{3}\right)_{2}(25-$ $50 \mathrm{mM}$ ) whereas, at higher concentrations (100-150 mM), BSL was completely inhibited. The inhibition of BSL by $\mathrm{Cu}^{++}$, a transition metal ion, might be due to the changes brought by metal ion in solubility and behavior of ionized fatty acid at the interfaces affecting the catalytic properties of enzyme [37]. At all concentrations of $\mathrm{CoCl}_{2}, \mathrm{CdCl}_{2}$, and $\mathrm{HgCl}_{2}, \mathrm{BSL}$ lost its $100 \%$ original activity indicating highly potent inhibitory nature of these metals.

3.8. Effect of Chemical Modulators on BSL Activity. Table 3 shows the effect of different chemical modulators $\mathrm{H}_{2} \mathrm{O}_{2}$, PMSF, EDTA, bile salts, orlistat, and oleic acid at $5 \mathrm{mM}$ conc. on BSL activity. Among the different compounds tested, BSL activity was greatly reduced by $83.33 \%$ in presence of PMSF indicating it as a member of serine family. The inhibition occurring in presence of PMSF might be due to modification of essential serine residue, inducing a direct or indirect change in enzyme confirmation [38, 39]. A considerable inhibition in BSL activity was recorded in presence of EDTA $(50.01 \%)$ and urea $(50.01 \%)$. Inhibition in presence of EDTA indicated that the BSL is metalloenzyme [40]. Oleic acid is an end product of olive oil hydrolysis mediated by lipase action. BSL activity was reduced by $80 \%$ when enzyme was preincubated in presence of oleic acid. The drastic reduction of BSL activity in presence of oleic acid might be due to the end product inhibition, a regulatory process in which the metabolite formed in downstream reactions inhibits the activities of upstream enzyme [41].

\section{Conclusion}

In the present study, a highly thermostable alkaline lipase from a desert isolate Bacillus sonorensis 4R was isolated and characterized. On the basis of results, BSL can be used as a potential candidate in various industrial and biotechnological sectors with special mention as additives in detergents and food industries, environmental bioremediations, and molecular biology. However, further works relating to improvement in enzyme yield and other kinetic aspects of enzyme activity are required to understand the catalytic properties of this enzyme. Statistical approach based optimization of BSL production and structural elucidation of lipase is in progress. 
TABLE 2: Kinetic and thermodynamic parameters for thermal denaturation of BSL.

\begin{tabular}{lccccc}
\hline Temperature $\left({ }^{\circ} \mathrm{C}\right)$ & $t_{1 / 2}$ & $K_{d}$ & $\Delta H\{$ enthalpy $(\mathrm{KJ} / \mathrm{mol})\}$ & $\Delta G\{$ free energy $(\mathrm{KJ} / \mathrm{mol})\}$ & $\Delta S\{$ entropy $(\mathrm{J} / \mathrm{mol} / \mathrm{K})\}$ \\
\hline 80 & 150 & $46 * 10^{-4}$ & 28.16 & 102.79 & -0.211 \\
90 & 121.59 & $57 * 10^{-4}$ & 28.08 & 105.12 & -0.212 \\
100 & 90 & $77 * 10^{-4}$ & 28.00 & 110.28 & -0.220 \\
110 & 70 & $99 * 10^{-4}$ & 27.91 & 109.32 & -0.212 \\
120 & 50 & $138 * 10^{-4}$ & 27.83 & 111.66 & -0.211 \\
\hline
\end{tabular}

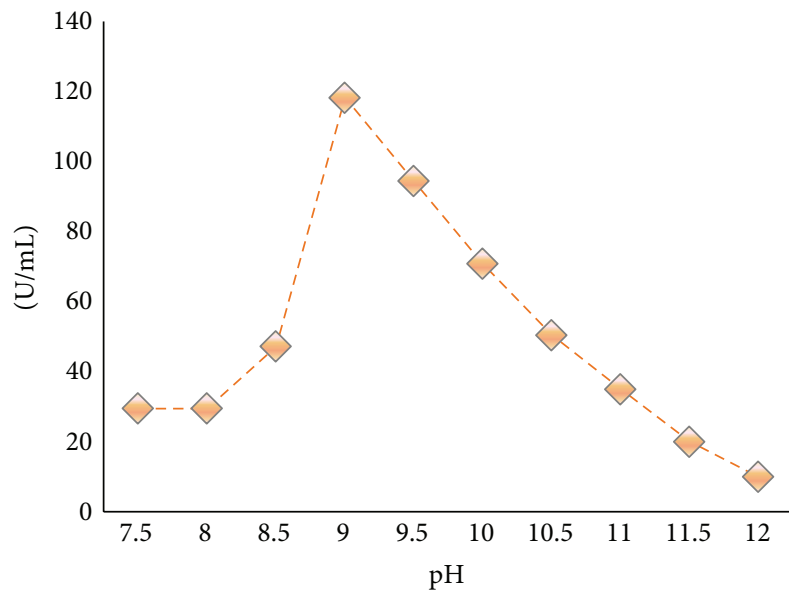

(a)

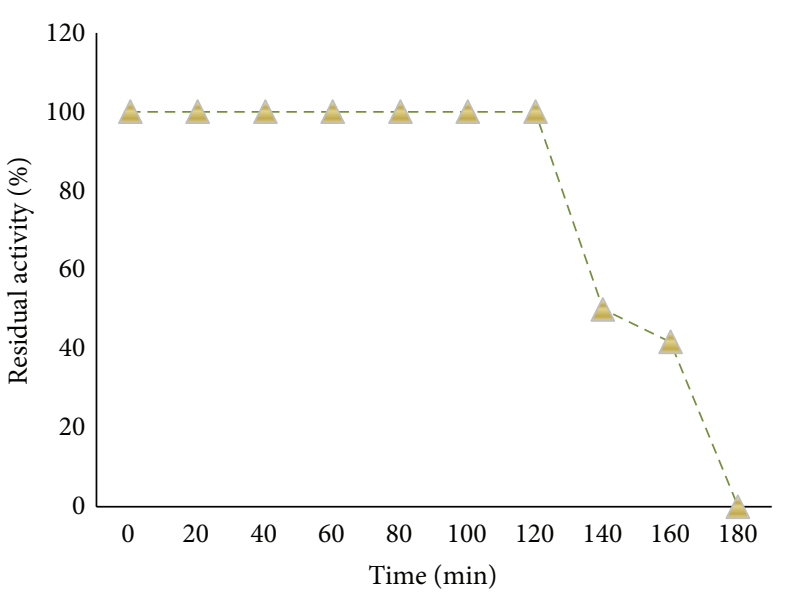

(b)

Figure 9: (a) Effect of $\mathrm{pH}$ on BSL activity at $80^{\circ} \mathrm{C}$. BSL activity at $\mathrm{pH} 9.0$ was set as $100 \%$. (b) Stability of BSL at pH 9.0. BSL activity without preincubation was set as $100 \%$.

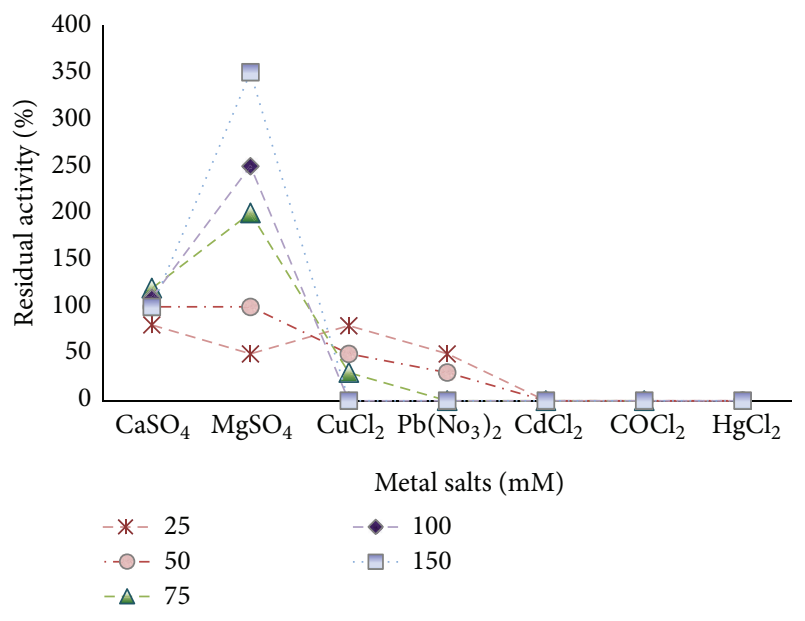

FIGURE 10: Effect of metal ions on BSL activity. BSL activity without amendment of metal ions was set as $100 \%$.

\section{Conflict of Interests}

The authors declare that there is no conflict of interests regarding the publication of this paper.

\section{Acknowledgment}

The authors wish to acknowledge the School of Life Sciences, Swami Ramanand Teerth Marathwada University, Nanded
TABLE 3: Effect of chemical modulators on BSL activity. Residual activity of BSL was determined by comparing activities before incubation of BSL in presence of modulators.

\begin{tabular}{lc}
\hline Chemical modulators & Residual activity (\%) \\
\hline EDTA & 49.99 \\
Urea & 49.99 \\
PMSF & 16.67 \\
Iodine & 20 \\
Orlistat & 20 \\
Oleic acid & 20 \\
\hline
\end{tabular}

(M.S., India), for providing support and necessary facilities to complete this research work.

\section{References}

[1] C. Vieille and G. J. Zeikus, "Hyperthermophilic enzymes: sources, uses, and molecular mechanisms for thermostability," Microbiology and Molecular Biology Reviews, vol. 65, no. 1, pp. $1-43,2001$.

[2] C. Vieille, D. S. Burdette, and J. G. Zeikus, "Thermozymes," Biotechnology Annual Review, vol. 2, pp. 1-83, 1996.

[3] G. D. Haki and S. K. Rakshit, "Developments in industrially important thermostable enzymes: a review," Bioresource Technology, vol. 89, no. 1, pp. 17-34, 2003. 
[4] D. A. Cowan and R. Fernandez-Lafuente, "Enhancing the functional properties of thermophilic enzymes by chemical modification and immobilization," Enzyme and Microbial Technology, vol. 49, no. 4, pp. 326-346, 2011.

[5] Dublin Business Wire and Research and Markets, "Lipase market by source, application and by geography_-global forecast to brochure research and markets 2020," The World's Largest Market Research Store, 2015, http://www.researchandmarkets.com/ reports/3388717.

[6] P. K. Ghosh, R. K. Saxena, R. Gupta, R. P. Yadav, and S. Davidson, "Microbial lipases: production and applications," Science Progress, vol. 79, pp. 119-157, 1996.

[7] R. K. Saxena, P. K. Ghosh, R. Gupta, W. S. Davidson, S. Bradoo, and R. Gulati, "Microbial lipases: potential biocatalysts for the future industry," Current Science, vol. 77, no. 1, pp. 101-115, 1999.

[8] C. Yao, Y. Cao, S. Wu, S. Li, and B. He, "An organic solvent and thermally stable lipase from Burkholderia ambifaria YCJ01: purification, characteristics and application for chiral resolution of mandelic acid," Journal of Molecular Catalysis B: Enzymatic, vol. 85-86, pp. 105-110, 2013.

[9] M. Masomian, R. N. Z. R. A. Rahman, A. B. Salleh, and M. Basri, "A new thermostable and organic solvent-tolerant lipase from Aneurinibacillus thermoaerophilus strain HZ," Process Biochemistry, vol. 48, no. 1, pp. 169-175, 2013.

[10] P. Rathi, S. Bradoo, R. K. Saxena, and R. Gupta, "A hyperthermostable, alkaline lipase from Pseudomonas sp. with the property of thermal activation," Biotechnology Letters, vol. 22, no. 6, pp. 495-498, 2000.

[11] K. Selvam, B. Vishnupriya, and S. C. Bose, "Screening and quantification of marine actinomycetes producing industrial enzymes amylase, cellulose, lipase from south coast of India," International Journal of Pharmaceutical and Biological Archive, vol. 2, pp. 1481-1485, 2010.

[12] M. M. Bradford, "A rapid and sensitive method for the quantitation of microgram quantities of protein utilizing the principle of protein-dye binding," Analytical Biochemistry, vol. 72, no. 1-2, pp. 248-254, 1976.

[13] S. A. Arrhenius, "Über die dissociationswärme und den einfluss der temperatur auf den dissociationsgrad der elektrolyte," Zeitschrift für Physikalische Chemie, vol. 4, pp. 96-116, 1889.

[14] S. N. Gummadi, "What is the role of thermodynamics on protein stability?" Biotechnology and Bioprocess Engineering, vol. 8, no. 1, pp. 9-18, 2003.

[15] M. M. Palmisano, L. K. Nakamura, K. E. Duncan, C. A. Istock, and F. M. Cohan, "Bacillus sonorensis sp. nov., a close relative of Bacillus licheniformis, isolated from soil in the Sonoran Desert, Arizona," International Journal of Systematic and Evolutionary Microbiology, vol. 51, no. 5, pp. 1671-1679, 2001.

[16] M. Nerurkar, M. Joshi, and R. Adivarekar, "Bioscouring of cotton using lipase from marine bacteria Bacillus sonorensis," Applied Biochemistry and Biotechnology, vol. 175, no. 1, pp. 253265, 2015.

[17] T. Aanniz, M. Ouadghiri, M. Melloul et al., "Thermophilic bacteria in Moroccan hot springs, salt marshes and desert soils," Brazilian Journal of Microbiology, vol. 46, no. 2, pp. 443-453, 2015.

[18] N.-P. Hua, F. Kobayashi, Y. Iwasaka, G.-Y. Shi, and T. Naganuma, "Detailed identification of desert-originated bacteria carried by Asian dust storms to Japan," Aerobiologia, vol. 23, no. 4, pp. 291298, 2007.
[19] E. D. Lester, M. Satomi, and A. Ponce, "Microflora of extreme arid Atacama Desert soils," Soil Biology and Biochemistry, vol. 39, no. 2, pp. 704-708, 2007.

[20] L. Chopra, G. Singh, K. K. Jena, H. Verma, and D. K. Sahoo, "Bioprocess development for the production of sonorensin by Bacillus sonorensis MT93 and its application as a food preservative," Bioresource Technology, vol. 175, pp. 358-366, 2015.

[21] U. Pandya and M. Saraf, "Isolation and identification of allelochemicals produced by $B$. sonorensis for suppression of charcoal rot of Arachis hypogaea L.," Journal of Basic Microbiology, vol. 55, no. 5, pp. 635-644, 2015.

[22] R. Tian, H. Chen, Z. Ni et al., "Expression and characterization of a novel thermo-alkalistable lipase from hyperthermophilic bacterium Thermotoga maritima," Applied Biochemistry and Biotechnology, vol. 176, no. 5, pp. 1482-1497, 2015.

[23] T. Wei, S. Feng, D. Mao, X. Yu, C. Du, and X. Wang, "Characterization of a new thermophilic and acid tolerant esterase from Thermotoga maritima capable of hydrolytic resolution of racemic ketoprofen ethyl ester," Journal of Molecular Catalysis B: Enzymatic, vol. 85-86, pp. 23-30, 2013.

[24] K. Chakraborty and R. P. Raj, "An extra-cellular alkaline metallolipase from Bacillus licheniformis MTCC 6824: purification and biochemical characterization," Food Chemistry, vol. 109, no. 4, pp. 727-736, 2008.

[25] F. M. Shariff, R. N. Z. R. A. Rahman, M. Basri, and A. B. Salleh, "A newly isolated thermostable lipase from Bacillus sp.", International Journal of Molecular Sciences, vol. 12, no. 5, pp. 2917-2934, 2011.

[26] T. H. T. A. Hamid, M. A. Eltaweel, R. N. Z. R. A. Rahman, M. Basri, and A. B. Salleh, "Characterization and solvent stable features of Strep-tagged purified recombinant lipase from thermostable and solvent tolerant Bacillus sp. strain 42," Annals of Microbiology, vol. 59, no. 1, pp. 111-118, 2009.

[27] J. Zhang, J. F. Liu, J. Zhou, Y. Y. Ren, X. Y. Dai, and H. Xiang, "Thermostable esterase from Thermoanaerobacter tengcongensis: high-level expression, purification and characterization," Biotechnology Letters, vol. 25, no. 17, pp. 1463-1467, 2003.

[28] H. Klump, J. Di-Ruggiero, M. Kessel, J. B. Park, M. W. W. Adams, and F. T. Robb, "Glutamate dehydrogenase from the hyperthermophile Pyrococcus furiosus," The Journal of Biological Chemistry, vol. 267, pp. 22681-22685, 1992.

[29] K.-E. Jaeger, S. Ransac, B. W. Dijkstra, C. Colson, M. van Heuvel, and O. Misset, "Bacterial lipases," FEMS Microbiology Reviews, vol. 15, no. 1, pp. 29-63, 1994.

[30] L. Cui, G. Du, D. Zhang, and J. Chen, “Thermal stability and conformational changes of transglutaminase from a newly isolated Streptomyces hygroscopicus," Bioresource Technology, vol. 99, no. 9, pp. 3794-3800, 2008.

[31] S. P. George, A. Ahmad, and M. B. Rao, "A novel thermostable xylanase from Thermomonospora sp.: influence of additives on thermostability," Bioresource Technology, vol. 78, no. 3, pp. 221224, 2001.

[32] S. A. Costa, T. Tzanov, A. F. Carneiro, A. Paar, G. M. Gübitz, and A. Cavaco-Paulo, "Studies of stabilization of native catalase using additives," Enzyme and Microbial Technology, vol. 30, no. 3, pp. 387-391, 2002.

[33] A. Cobos and P. Estrada, "Effect of polyhydroxylic cosolvents on the thermostability and activity of xylanase from Trichoderma reesei QM 9414," Enzyme and Microbial Technology, vol. 33, no. 6, pp. 810-818, 2003. 
[34] W. Bankeeree, P. Lotrakul, S. Prasongsuk et al., "Effect of polyols on thermostability of xylanase from a tropical isolate of Aureobasidium pullulans and its application in prebleaching of rice straw pulp," SpringerPlus, vol. 3, article 37, 2014.

[35] D. Fu, C. Li, J. Lu, A. U. Rahman, and T. Tan, "Relationship between thermal inactivation and conformational change of Yarrowia lipolytica lipase and the effect of additives on enzyme stability," Journal of Molecular Catalysis B: Enzymatic, vol. 66, no. 1-2, pp. 136-141, 2010.

[36] H. N. Bhatti and F. Amin, "Kinetic and hydrolytic characterization of newly isolated alkaline lipase from ganoderma lucidum using canola oil cake as substrate," Journal of the Chemical Society of Pakistan, vol. 35, no. 3, pp. 585-592, 2013.

[37] H. Dong, S. Gao, S.-P. Han, and S.-G. Cao, "Purification and characterization of a Pseudomonas sp. lipase and its properties in non-aqueous media," Biotechnology and Applied Biochemistry, vol. 30, no. 3, pp. 251-256, 1999.

[38] J. Ma, Z. Zhang, B. Wang et al., "Overexpression and characterization of a lipase from Bacillus subtilis," Protein Expression and Purification, vol. 45, no. 1, pp. 22-29, 2006.

[39] A. Sugihara, T. Tani, and Y. Tominaga, "Purification and characterization of a novel thermostable lipase from Bacillus sp.", Journal of Biochemistry, vol. 109, no. 2, pp. 211-216, 1991.

[40] G. T. James, "Inactivation of the protease inhibitor phenylmethylsulfonyl fluoride in buffers," Analytical Biochemistry, vol. 86, no. 2, pp. 574-579, 1978.

[41] R. M. Denton and C. L. Pogson, Metabolic Regulation, Chapmon and Hall, 1976. 

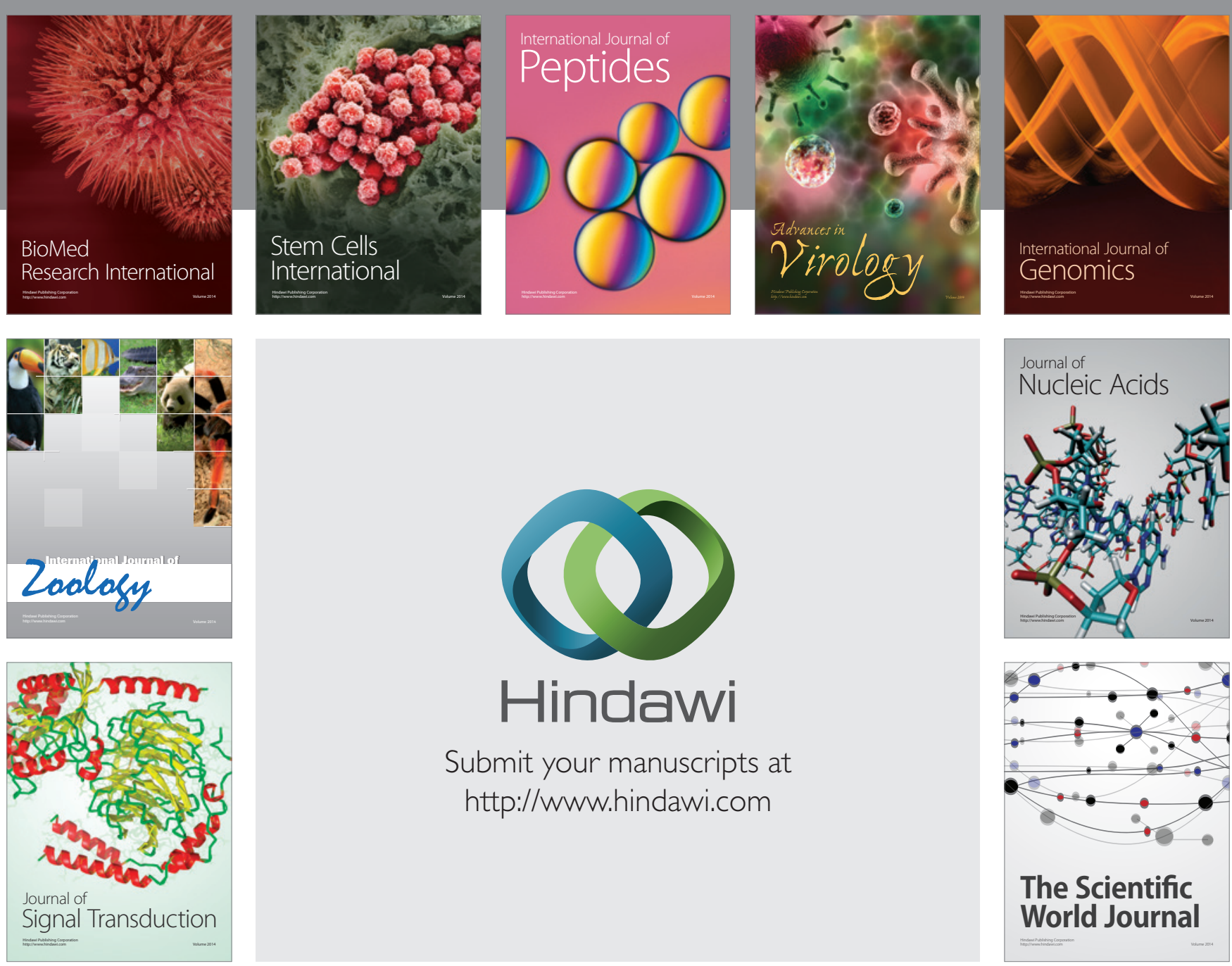

Submit your manuscripts at

http://www.hindawi.com
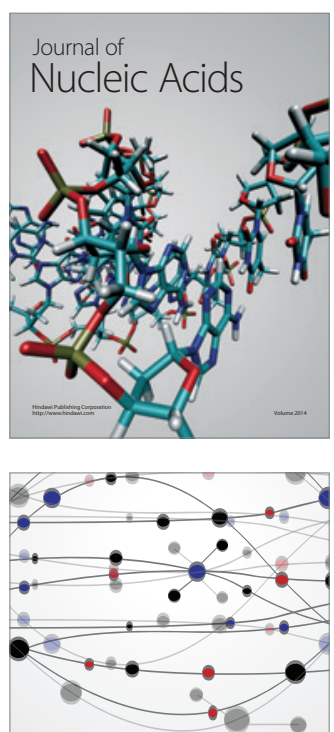

The Scientific World Journal
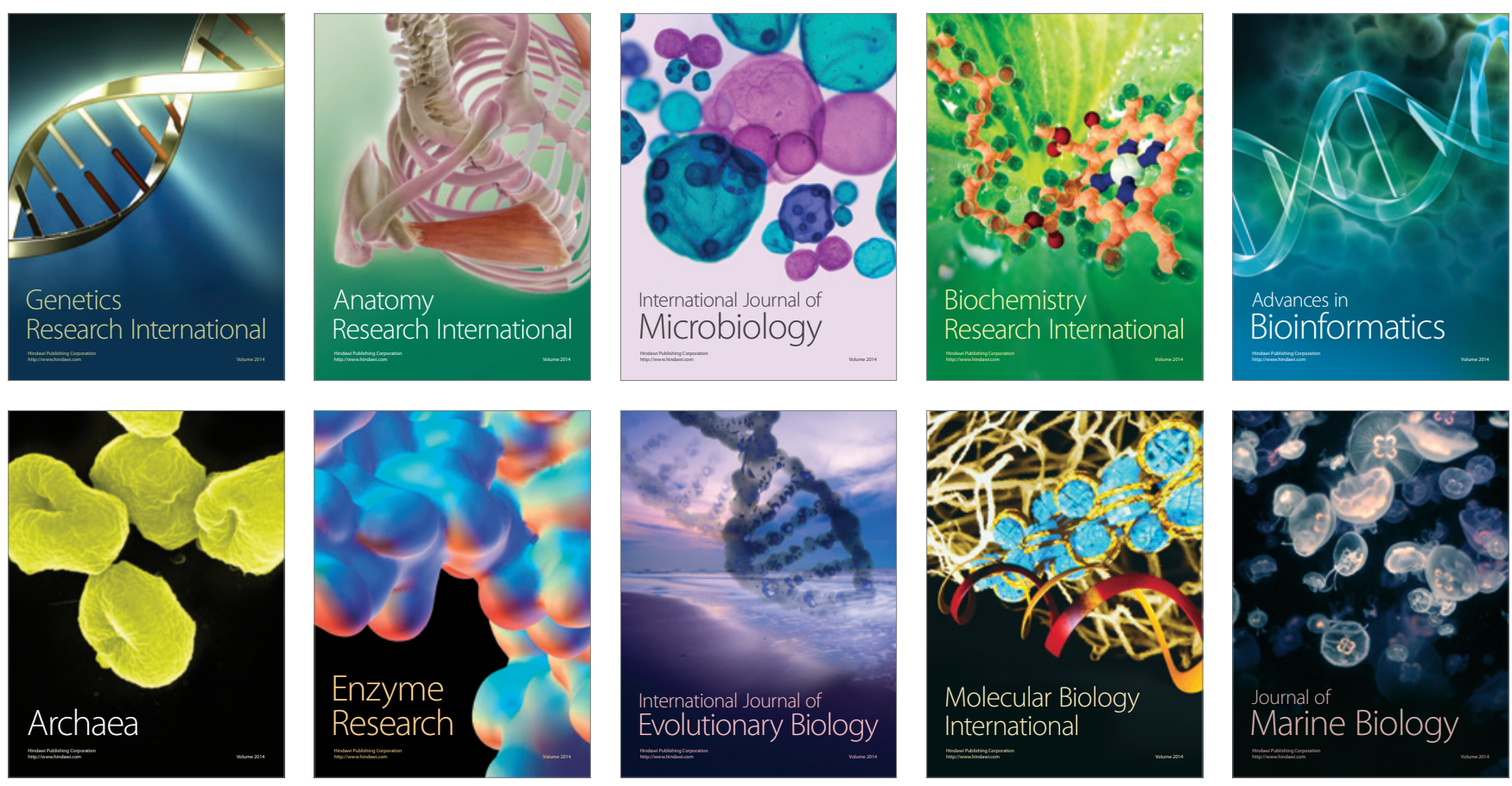